\title{
Journal of Bacteriology and

\section{Characterization of Soluble and Membrane-Bound Proteins of Toxoplasma gondii as Diagnostic Markers of Infection}

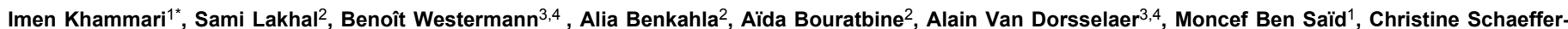
Reiss $^{3,4}$ and Fatma Saghrouni ${ }^{1}$

${ }^{1}$ Laboratory of Parasitology, Farhat Hached University Hospital, Ibn Jazzar Street, Sousse 4000, Tunisia

${ }^{2}$ Research Laboratory of Medical Parasitology, Biotechnology and Biomolecules, LR 11 IPT06 Pasteur Institute of Tunis, Tunisia

${ }^{3}$ BioOrganic Mass Spectrometry Laboratory (LSMBO), IPHC, Université de Strasbourg, 25 rue Becquerel, 67087 Strasbourg, France

${ }^{4}$ IPHC, CNRS, UMR7178, 67087 Strasbourg, France

*Corresponding author: Imen Khammari, Laboratory of Parasitology. Farhat Hached University Hospital, Ibn Jazzar Street, Sousse 4000 , Tunisia, Tel: +216 732214 11; Fax: +216 732267 02; E-mail: imenkhammari@yahoo.fr

Received date: July 23, 2015; Accepted date: August 19 2015; Published date: August 24, 2015

Copyright: (C) 2015 Khammari et al. This is an open-access article distributed under the terms of the Creative Commons Attribution License, which permits unrestricted use, distribution, and reproduction in any medium, provided the original author and source are credited.

\begin{abstract}
In the present study, we applied the combination of one-dimensional gel electrophoresis, immunoblot and nanoliquid chromatography-tandem mass spectrometry (nanoLC-MS/MS) to identify potential immunogenic proteins of Toxoplasma gondii tachyzoites that can be used for the development of reliable assays in the serodiagnosis of acquired toxoplasmosis in immunocompetent subjects. For this purpose, we developed an immunoblot using soluble and membrane extracts of GT1 Toxoplasma gondii tachyzoites and tested 194 positive and 100 negative sera obtained from pregnant women.
\end{abstract}

Five bands of soluble antigens (98 kDa, $36 \mathrm{kDa}, 33 \mathrm{kDa}, 32 \mathrm{kDa}$ and $21 \mathrm{kDa}$ ) and 4 bands of membrane antigens (41 kDa, $35 \mathrm{kDa}, 32 \mathrm{kDa}$ and $30 \mathrm{kDa}$ ) were selected as the most valuable in terms of sensitivity and specificity. Among these bands, only 2 bands of soluble antigen ( $33 \mathrm{kDa}$ and $32 \mathrm{kDa}$ ) and 2 bands of membrane antigen ( 32 $\mathrm{kDa}$ and $30 \mathrm{kDa}$ ) showed a specificity $\geq 90 \%$.

After mass spectrometry and bioinformatics analysis, 7 proteins were identified as potential markers for serodiagnosis of toxoplasmosis. These proteins are: SRS34A, GRA7, GRA1, DG32, MIC5, ROP5 and Toxofilin. These proteins showed a $86 \%$ to $100 \%$ homology with proteins of both VEG and ME49 strains of $T$. gondii and a $58 \%$ to $87 \%$ homology with Hammondia hammondi; and can be considered as attractive candidates for the development of an immunochromatography test that can be used for the rapid diagnosis of toxoplasmosis and as a confirmatory test when routine techniques give equivocal results.

Keywords: Toxoplasmosis; $\quad$ Serodiagnosis; Tachyzoites; Immunoblot; NanoLC-MS/MS

\section{Introduction}

Toxoplasmosis is a parasitic disease caused by an obligate Apicomplexa intracellular protozoan parasite, Toxoplasma gondii that is widely distributed and can infect humans and warm blooded animals [1-3]. In immunocompetent individuals, toxoplasmosis is usually asymptomatic, whereas in immunocompromised patients (human immunodeficiency virus infected patients, organ and bone marrow transplanted patients), it can cause life-threatening infections. Moreover, in non-immune (without any anti-Toxoplasma antibodies) pregnant women, it may cause severe lesions in the fetus, because of the risk of transplacental transmission [4-6]. For this reason, the determination and the correct interpretation of the immune status of the mother towards toxoplasmosis are crucial for appropriate followup, prophylactic measures and treatment $[5,7]$

The diagnosis of toxoplasmosis in immunocompetent individuals is based on serology by the search of IgG and IgM anti-Toxoplasma antibodies. For this purpose, a variety of commercial serological tests has been developed; the most widely used being the automated enzyme immunoassays $[5,6,8]$. Even though most of these assays are overall satisfactory with respect to sensitivity and specificity, equivocal results and discordances between kits are not uncommon especially when the titer of specific IgG is low or close to the cut-off value of the test, despite many efforts for international standardization $[9,10]$.

Tachyzoites of $T$. gondii are responsible of the acute phase of the infection, which they activate a potent host immune response that eliminates most of the parasites [2,11]. The identification and characterization of immunogenic proteins, whether from the soluble tachyzoite antigens ([ST-Ag], cytoplasmic and secreted/excreted antigens) or the membrane tachyzoite antigens ([MT-Ag], constituents of the cytoplasmic membrane), have been the focus of an extensive research. Both antigenic fractions may contain proteins of relevant antigenicity that needs to be identified.

Immunoproteomics combining one-dimensional sodium dodecyl sulfate polyacrylamide gel electrophoresis (1D-SDS-PAGE) followed by immunoblot and nano-liquid chromatography-tandem mass spectrometry (nanoLC-MS/MS) analysis is a powerful tool for the identification of proteins with diagnostic value $[6,12-14]$.

In the present study, we applied this approach to identify potential immunogenic proteins of $T$. gondii tachyzoites that can be used for the 
development of reliable assays in the serodiagnosis of acquired toxoplasmosis in immunocompetent subjects.

\section{Materials and Methods}

\section{Parasites}

Seventy female Swiss albino mice weighing 30-35 g were used for the preparation of antigens. Mice were kept at $22-24^{\circ} \mathrm{C}$, under humidity level of $45-75 \%$ and provided with food and water ad libitum in animal facilities. Then, they were intraperitoneally injected with 50 $\mu \mathrm{L}$ of a suspension of the virulent GT1 T. gondii strain tachyzoites at $10^{3}-10^{4}$ tachyzoites $/ \mathrm{ml}$. Three days after infection, mice were euthanized by carbon dioxide inhalation and the peritoneal exudates were collected and pooled. The monitoring of mice was performed according to the criteria set by Montgomery [15]. All experimentations were performed according to the directive 2010/63/UE of the European Parliament and the Council.

\section{Preparation of $T$. gondii tachyzoites antigens}

Preparation of ST-Ag: Preparation of ST-Ag was carried out according to Ma et al. with minor modifications [2] (Annex 1).

Preparation of MT-Ag: Preparation of MT-Ag was carried out according to Robinson et al. [16] (Annex 2).

\section{One dimensional SDS-PAGE}

1D-SDS-PAGE was performed under denaturing and reducing conditions with a $12 \%$ acrylamide- $5 \%$ bisacrylamide gel as described by Laemmli [17]. The Mini-Protean Tetra Cel (Bio-Rad, Marnes-LaCoquette, France) was used as a vertical electrophoresis system. The molecular weight marker See Blue Pre-Stained Standard (Invitrogen) was used.

After migration, the gel was stained with Coomassie blue R-250. The images of the gel were obtained by the Chemi Doc TM MP imaging system and then analysed using the Quantity One Software package (Bio-Rad).

\section{Immunoblot}

Once the 1D-SDS-PAGE was finalized, proteins were transferred from the gel to a nitrocellulose membrane for $90 \mathrm{~min}$ at $50 \mathrm{~V}$ and $+4^{\circ} \mathrm{C}$. The membrane was cut into strips and blocked in $5 \%$ dried skimmed milk in PBS-T (PBS $10 \mathrm{mM}$ containing 0.3\% Tween 20) for 2 $\mathrm{h}$ at room temperature, then incubated overnight at $4^{\circ} \mathrm{C}$ with the diluted patient's serum (1/100 in PBS-T) under agitation. After five washes for $5 \mathrm{~min}$ in PBS-T and incubation with alkaline phosphatasegoat anti-human IgG antibody (1/6000) (Invitrogen) for $90 \mathrm{~min}$, proteins were revealed using the NitroBlue Tetrazolium-5-Bromo-4Chloro-3-Indolyl Phosphate (NBT/BCIP) substrate (Invitrogen) according to the manufacturer's instructions and the reaction was blocked with two washes of double-distilled $\mathrm{H}_{2} \mathrm{O}\left(\mathrm{ddH}_{2} \mathrm{O}\right)$. The molecular weight of the revealed bands was determined using the Quantity One software package.

\section{Sera}

All sera used in this study were analysed in the laboratory of Parasitology of Farhat Hached teaching hospital, Sousse, Tunisia. All of them were anonymized before use.
Inclusion criteria: We included sera collected from pregnant women, without any history of immunodeficiency, for routine toxoplasmosis screening. We randomly selected 294 sera we divided into 2 groups:

Group I: Consisted of 194 sera positive by Enzyme-Linked ImmunoSorbent Assay [ELISA-IgG (Platelia Toxo IgG, Bio-Rad, Marnes-La-Coquette, France)] and Indirect Fluorescent Antibody Test [IFAT-IgG (Toxo-Spot IF, Bio-Merieux, Marcy l'Etoile, France)]. Among them, 37 were positive in ELISA-IgM (Platelia Toxo IgM, BioRad, Marnes-La-Coquette, France). All sera were tested in immunoblot with ST-Ag and 126 of them were tested in immunoblot with MT-Ag.

Group II: Consisted of 100 sera negative in ELISA-IgG, ELISA-IgM and IFAT-IgG; all were tested in immunoblot with ST-Ag and 96 of them were tested in immunoblot with MT-Ag.

Exclusion criteria: We excluded sera from patients with symptomatic toxoplasmosis, sera from immunodeficient patients and from neonates.

\section{Statistical analysis}

The chi-square test was used to compare the frequencies of each band in both groups of positive and negative sera. The data were coded and entered into Epi Info ${ }^{\text {TM }} 6.04$ software (Centers for Disease Control and Prevention, Atlanta, Georgia, USA). The statistical significance was accepted at the 5\% level of significance and a $95 \%$ confidence level.

\section{Protein Identification by nanoLC-MS/MS}

\section{Sample preparation}

Coomassie blue stained protein bands, corresponding to the proteins which were the more reactive with the positive sera, were manually excised from the gel and washed with $\mathrm{ddH}_{2} \mathrm{O}$.

\section{In gel tryptic digestion}

In-gel digestion was performed with an automated protein digestion system, MassPREP Station (Waters, Manchester, UK). The gel bands were washed twice with $50 \mu \mathrm{L}$ of mixture containing $25 \mathrm{mM}$ ammonium bicarbonate/acetonitrile $(1: 1, \mathrm{v} / \mathrm{v})$ for $10 \mathrm{~min}$ in order to remove the Coomassie blue excess. After dehydratation for $5 \mathrm{~min}$ with acetonitrile (ACN), cysteine residues were reduced by $50 \mu \mathrm{L}$ of $10 \mathrm{mM}$ dithiothreitol prepared in $25 \mathrm{mM}$ ammonium bicarbonate at $60^{\circ} \mathrm{C}$ for $1 \mathrm{~h}$, and alkylated with $50 \mu \mathrm{L}$ of $55 \mathrm{mM}$ iodoacetamide prepared in 25 $\mathrm{mM}$ ammonium bicarbonate at room temperature for $20 \mathrm{~min}$. Gel bands were washed with $100 \mu \mathrm{L}$ of $25 \mathrm{mM}$ ammonium bicarbonate solution and dehydrated with ACN. Proteins were digested in gel with $20 \mu \mathrm{L}$ of a $4.7 \mathrm{ng} / \mu \mathrm{L}$ modified porcine trypsin (Promega, Madison, WI, USA) in $25 \mathrm{mM}$ ammonium bicarbonate at $37^{\circ} \mathrm{C}$ overnight. Trypsin cleaves proteins on the $\mathrm{C}$-terminal side of lysine and arginine amino acid residues, except when either is followed by proline. Peptides were extracted with $35 \mu \mathrm{L}$ of an aqueous solution containing $60 \% \mathrm{ACN}$ $(\mathrm{v} / \mathrm{v})$ and $1.0 \%$ formic acid $(\mathrm{v} / \mathrm{v})$, under agitation for $2 \mathrm{~h}$ at room temperature. Excess of ACN was removed by Speed Vac treatment and peptides were resuspended in $30 \mu \mathrm{L}$ of an aqueous solution containing $0.1 \%$ formic acid prior to nanoLC-MS/MS analysis. 
Citation: Khammari I, Lakhal S, Westermann B, Benkahla A, Bouratbine A, et al. (2015) Characterization of Soluble and Membrane-Bound Proteins of Toxoplasma gondii as Diagnostic Markers of Infection. J Bacteriol Parasitol 6: 239. doi:10.4172/2155-9597.1000239

Page 3 of 10

\section{NanoLC-MS/MS analysis}

Peptides were analyzed on a nano-ACQUITY Ultra-PerformanceLC system (UPLC, Waters, Milford, MA, USA) hyphenated to a MaXis4G (Bruker Daltonics, Bremen, Germany).

Peptides were first trapped on a $0.18 \mathrm{~mm} \times 20 \mathrm{~mm}, 5 \mu \mathrm{m}$ Symmetry C18 pre-column (Waters), and then separated on an ACQUITY UPLC BEH130 C18 column (Waters), $75 \mu \mathrm{m} \times 250 \mathrm{~mm}$ with $1.7 \mu \mathrm{m}$ particle size. The solvent system consisted of $0.1 \%$ formic acid in water (solvent $\mathrm{A}$ ) and $0.1 \%$ formic acid in $\mathrm{ACN}$ (solvent B). Trapping was performed for $3 \mathrm{~min}$ at $5 \mu \mathrm{L} / \mathrm{min}$ with $99 \%$ solvent $A$ and $1 \%$ solvent B. Elution was performed at a flow rate of $450 \mathrm{~nL} / \mathrm{min}$, using a $6-35 \%$ gradient (solvent B) over $30 \mathrm{~min}$ at $60^{\circ} \mathrm{C}$.

The mass spectrometer was equipped with a Captive Spray source and a nano-Booster operating in positive mode with the following settings: source temperature was set at $150^{\circ} \mathrm{C}$ while drying gas flow was at $3 \mathrm{~L} / \mathrm{min}$. The nano-electrospray voltage was optimized to -1300 $\mathrm{V}$. External mass calibration of the TOF was achieved before each set of analyses using Tuning Mix (Agilent Technologies, Palo Alto, CA, USA) in the mass range of $322-2722 \mathrm{~m} / \mathrm{z}$. Mass correction was achieved by recalibration of acquired spectra to the applied lock masses hexakis $\left(2,2,3,3\right.$,-tetrafluoropropoxy) phosphazine $\left([\mathrm{M}+\mathrm{H}]^{+}=\right.$ $922.0098 \mathrm{~m} / \mathrm{z}])$.

For tandem MS experiments (Collision-Induced Dissociation), the acquisition was performed by sequentially selecting the maximum of precursors for a cycle time of $3 \mathrm{~s}$, with a preference for multiply charged ions and strict exclusion of monocharged ions. The fragmentation was performed using argon as collision gas.

Acquisition speed in MS/MS was adjusted according to the intensity of the precursor. Selected ions were excluded for $1 \mathrm{~min}$ and optionally reconsidered if the measured intensity was three times higher than the previous measured intensity. The complete system was piloted and controlled by Hystar 3.2 software (Bruker Daltonics, GmbH, Bremen, Germany).

\section{Protein identification}

Raw data collected during nanoLC-MS/MS analysis were processed and converted into "mascotgenericfile"(mgf) with DataAnalysis 4.0
(Bruker Daltonics, Bremen, Germany). All mgf files were interpreted using MASCOT 2.4.3 search engine algorithm (Matrix Science, London, UK) running on a local server. Searches were performed without any molecular weight or isoelectric point restrictions against an in-house generated protein database composed of protein sequences of $T$. gondii (ToxoDB database, 24 April 2014) and known contaminant proteins such as human keratins and trypsin. All proteins were concatenated with reversed copies of all sequences (49.328 entries) with an in-house database generation toolbox [18]. Trypsin was selected as enzyme, carbamidomethylation of cysteine (+57 Da) was set as fixed modification, oxidation of methionine (+16 Da) were set as variable modification and both precursor and fragment mass tolerances were adapted according to instrumental mass accuracy. The MASCOT results were loaded into 3.6.5 Scaffold software (Proteome Software, Portland, OR) to validate peptide identifications. The targetdecoy search strategy allowed us to control the protein false discovery rate which was set to a maximum of $1 \%$ [19].

\section{Bioinformatics analysis}

The proteins listed in the Raw data with coverage $\geq 40 \%$ were extracted and blasted against ToxoDB.org (14 April 2015) and NCBI (National Center for Biotechnology Information) non-redundant protein sequence database, respectively [20]. Both blasts were carried out to check the similarity of these proteins against cogent proteins of their closest relatives (Hammondia, Neospora, and Eimeria), any related other organisms, and of humans.

\section{Results}

\section{ST-Ag-immunoblot}

A total of 28 bands with an apparent molecular weight ranging from 6 to $250 \mathrm{kDa}$ were detected by positive and negative sera. Out of the 28 bands, 5 bands (ST-98, ST-36, ST-33, ST-32 and ST-21 kDa) showed the highest specificity and/or sensitivity and were selected as the most relevant markers of infection (Table 1 and Figure 1).

\begin{tabular}{|c|c|c|c|c|c|c|c|}
\hline $\begin{array}{l}\text { Bands } \\
\mathrm{kDa}^{\mathrm{a}}\end{array}$ & $\begin{array}{l}\text { Positive sera } \\
{[n=194]}\end{array}$ & $\begin{array}{l}\text { Negative sera } \\
{[n=100]}\end{array}$ & $\begin{array}{l}\text { Sensitivity\% } \\
{\left[\mathrm{CL}^{\mathrm{b}} \text { 95\%] }\right.}\end{array}$ & $\begin{array}{l}\text { Specificity\% } \\
\text { [CL 95\%] }\end{array}$ & $\begin{array}{l}\text { PPVc\% } \\
\text { [CL 95\%] }\end{array}$ & $\begin{array}{l}\text { NPV }{ }^{\mathrm{d} \%} \\
\text { [CL 95\%] }\end{array}$ & $\begin{array}{l}P \text { value } \\
(<0.05)\end{array}$ \\
\hline$S T^{\mathrm{e}}-98$ & 165 & 13 & $85.1[79.1-89.6]$ & $87.0[78.4-92.6]$ & 92.7 [87.6-95.9] & $75.0[65.9-82.4]$ & $<10^{-4}$ \\
\hline ST-36 & 182 & 11 & $93.8[89.2-96.6]$ & 89.0 [80.8-94.1] & 94.3 [89.8-97.0] & 88.1 [79.8-93.4] & $<10^{-4}$ \\
\hline ST-33 & 139 & 7 & 71.6 [64.7-77.8] & 93.0 [85.6-96.9] & $95.2[90.0-97.9]$ & $62.8[54.5-70.5]$ & $<10^{-4}$ \\
\hline ST-32 & 181 & 8 & 93.3 [88.6-96.2] & 92.0 [84.4-96.2] & 95.8 [91.5-98.0] & 87.6 [79.4-93.0] & $<10^{-4}$ \\
\hline ST-21 & 156 & 12 & $80.4[74.0-85.6]$ & 88.0 [79.6-93.4] & 92.9 [87.6-96.1] & 69.8 [60.9-77.5] & $<10^{-4}$ \\
\hline
\end{tabular}

aKilo Dalton, ${ }^{b}$ Confidence Level, cPositive Predictive Value, d Negative Predictive Value, e Soluble Tachyzoite antigens.

Table 1: Intrinsic characteristics of the 5 relevant bands $(98,36,33,32$, and $21 \mathrm{kDa})$ selected in immunoblot with soluble tachyzoite antigens (STAg). 
Citation: Khammari I, Lakhal S, Westermann B, Benkahla A, Bouratbine A, et al. (2015) Characterization of Soluble and Membrane-Bound Proteins of Toxoplasma gondii as Diagnostic Markers of Infection. J Bacteriol Parasitol 6: 239. doi:10.4172/2155-9597.1000239

Page 4 of 10

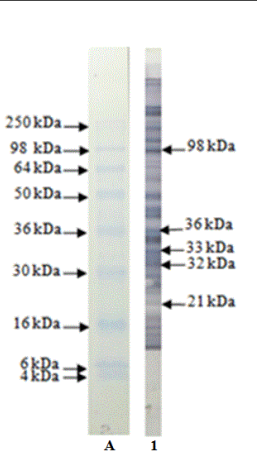

Figure 1: Example of pattern revealed in immunoblot with soluble tachyzoite antigens (ST-Ag) by one positive serum in ELISA and indirect fluorescent antibody test. A: Molecular weight marker. Lane 1: Pattern with the 98, 36, 33, 32 and $21 \mathrm{kDa}$ bands.
Out of the 5 bands, the ST- $32 \mathrm{kDa}$ and ST-33 kDa bands showed the highest specificity ( $92.0 \%$ and $93.0 \%$, respectively).

\section{MT-Ag-immunoblot}

A total of 26 bands with a apparent molecular weight ranging from 6 to $250 \mathrm{kDa}$ were detected by positive and negative sera. Out of the 26 bands, 4 bands (MT-41, MT-35, MT-32 and MT-30 kDa) showed the highest specificity and/or sensitivity and were selected as the most relevant markers of infection (Table 2 and Figure 2). Out of the 4 bands, the MT-30 kDa and MT-32 kDa bands showed the highest specificity ( $99.0 \%$ and $97.9 \%$, respectively).

All 9 bands were analysed by nanoLC-MS/MS and were subjected to bioinformatics analysis. In addition, the ST-32 kDa, ST-33 kDa, MT-32 $\mathrm{kDa}$ and MT-30 $\mathrm{kDa}$ that showed a specificity $\geq 90 \%$ were subjected to further analysis in order to identify and characterize the proteins they contain.

\begin{tabular}{|c|c|c|c|c|c|c|c|}
\hline $\begin{array}{l}\text { Bands } \\
\mathrm{kDa}^{\mathrm{a}}\end{array}$ & $\begin{array}{l}\text { Positive sera } \\
{[n=126]}\end{array}$ & $\begin{array}{l}\text { Negative sera } \\
{[n=96]}\end{array}$ & $\begin{array}{l}\text { Sensitivity\% } \\
\text { [CLb 95\%] }\end{array}$ & $\begin{array}{l}\text { Specificity\% } \\
\text { [CL 95\%] }\end{array}$ & $\begin{array}{l}\text { PPV \% } \\
\text { [CL 95\%] }\end{array}$ & $\begin{array}{l}\text { NPV } \% \\
\text { [CL 95\%] }\end{array}$ & $\begin{array}{l}P \text { value } \\
(<0.05)\end{array}$ \\
\hline $\mathrm{MT}^{\mathrm{e}}-41$ & 96 & 10 & $76.6[67.6-83.1]$ & 89.6 [81.3-94.6] & 90.6 [82.9-95.1] & 74.1 [65.0-81.6] & $<10^{-4}$ \\
\hline MT-35 & 116 & 11 & $92.1[85.5-95.9]$ & $88.5[80.0-93.9]$ & $91.3[84.7-95.4]$ & 89.5 [81.1-94.6] & $<10^{-4}$ \\
\hline MT-32 & 79 & 2 & $62.7[53.6-71.0]$ & 97.9 [92.0-99.6] & 97.5 [90.5-99.6] & 66.7 [58.2-74.2] & $<10^{-4}$ \\
\hline MT-30 & 96 & 1 & $76.2[67.6-83.1]$ & 99.0 [93.5-99.9] & 99.0 [93.6-99.9] & 76.0 [67.4-83.0] & $<10^{-4}$ \\
\hline
\end{tabular}

Table 2: Intrinsic characteristics of the 4 relevant bands $(41,35,32$ and $30 \mathrm{kDa})$ selected in immunoblot with membrane tachyzoite antigens (MT-Ag).

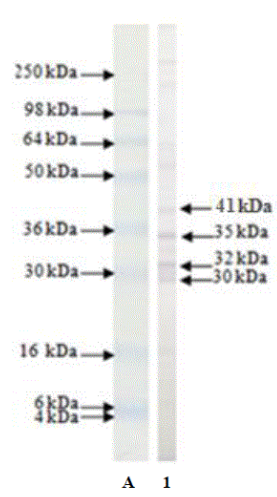

Figure 2: Example of pattern revealed in immunoblot with membrane tachyzoite antigens (MT-Ag) by one positive serum in ELISA and in Indirect Fluorescent Antibody Test. A: molecular weight marker. Lane 1: Pattern with the $41,35,32$ and $30 \mathrm{kDa}$ bands.

\section{Characterization of immunogenic proteins using the nanoLC-MS/MS and bioinformatics tools}

The Coomassie blue stained protein bands which were the more reactive with the positive sera $(\mathrm{ST}-98 \mathrm{kDa}, \mathrm{ST}-36 \mathrm{kDa}, \mathrm{ST}-33 \mathrm{kDa}$, ST-32 kDa, ST-21 kDa, MT-41 kDa, MT-35 kDa, MT-32 kDa and MT-30 kDa) were manually excised from the gel, digested with trypsin and analyzed by nanoLC-MS/MS. Thereafter, all 9 bands were subjected to bioinformatics analysis. Proteins that are in the 4 bands (ST-32 kDa, ST-33 kDa, MT-32 kDa and MT-30 kDa) that showed a specificity $\geq 90 \%$ were selected for bioinformatics analysis with respect to the similarity between GT1 strain and other T. gondii strains, on one hand, and between GT1 strain and non-Toxoplasma organisms, on the other hand.

A total of 732 proteins were generated from the 9 soluble and membrane proteins bands of $T$. gondii (Table 3 ).

Proteins with a sequence coverage $\geq 40 \%$ were selected for further investigation in order to better characterize the associated proteins. A total of 57 sets of proteins were generated from the 9 soluble and membrane proteins bands. Thirteen of them present sequence coverage $\geq 40 \%$ and a closest ortholog $\leq 90 \%$ (Table 3 ).

Four bands restricted to an antigenic specificity $\geq 90 \%$ (ST-33 kDa, ST-32 kDa, MT-32 kDa and MT-30 kDa) showed 7 different proteins (Table 3). 
Citation: Khammari I, Lakhal S, Westermann B, Benkahla A, Bouratbine A, et al. (2015) Characterization of Soluble and Membrane-Bound Proteins of Toxoplasma gondii as Diagnostic Markers of Infection. J Bacteriol Parasitol 6: 239. doi:10.4172/2155-9597.1000239

Page 5 of 10

\begin{tabular}{|c|c|c|c|c|c|c|}
\hline $\begin{array}{l}\text { Filtering } \\
\text { criteria }\end{array}$ & $\begin{array}{l}\text { Included protein } \\
\text { bands }\end{array}$ & $\begin{array}{l}\text { Bands specificity in } \\
\text { immunoblot } \\
(\%)\end{array}$ & $\begin{array}{l}\text { Number } \\
\text { identified } \\
\text { peptides }\end{array}$ & $\begin{array}{l}\text { Number } \\
\text { different } \\
\text { proteins }\end{array}$ & $\begin{array}{l}\text { Percentage } \\
\text { sequence coverage } \\
(\%)\end{array}$ & $\begin{array}{l}\text { Number of } \\
\text { discriminant } \\
\text { peptide(s) }\end{array}$ \\
\hline $\begin{array}{l}\text { Any protein } \\
\text { sequence coverage }\end{array}$ & $\begin{array}{l}\text { STa-98 kDa, ST-36 kDa, } \\
\text { ST-33 kDa, ST-32 kDa, } \\
\text { ST-21 kDa, MT'-41 kDa, } \\
\text { MT-35 kDa, MT-32 kDa, } \\
\text { MT-30 kDa. }\end{array}$ & any & 1933 & 732 & 0.25 to 80 & 1 to 39 \\
\hline $\begin{array}{l}\text { Protein sequence } \\
\text { coverage } \geq 40 \%\end{array}$ & $\begin{array}{l}\text { ST-98 kDa, ST-36 kDa, } \\
\text { ST-33 kDa, ST-32 kDa, } \\
\text { ST-21 kDa. }\end{array}$ & any & 61 & 46 & 40 to 80 & 1 to 39 \\
\hline $\begin{array}{l}\text { Protein sequence } \\
\text { coverage } \geq 40 \%\end{array}$ & $\begin{array}{l}\text { MT-41 kDa, MT-35 kDa, } \\
\text { MT-32 kDa, } \\
\text { MT-30 kDa. }\end{array}$ & any & 33 & 27 & 40 to 70 & 4 to 20 \\
\hline $\begin{array}{l}\text { Protein sequence } \\
\text { coverage } \geq 40 \%\end{array}$ & $\begin{array}{l}\text { ST-98 kDa, ST-36 kDa, } \\
\text { ST-33 kDa, ST-32 kDa, } \\
\text { ST-21 kDa, MT-41 kDa, } \\
\text { MT-35 kDa, MT-32 kDa, } \\
\text { MT-30 kDa. }\end{array}$ & any & 94 & 57 & 40 to 80 & 1 to 39 \\
\hline 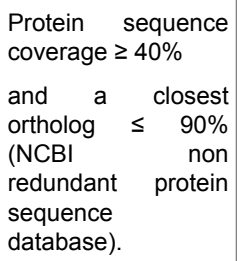 & $\begin{array}{l}\text { ST-98 kDa, ST-36 kDa, } \\
\text { ST-33 kDa, ST-32 kDa, } \\
\text { ST-21 kDa, MT-41 kDa, } \\
\text { MT-35 kDa, MT-32 kDa, } \\
\text { MT-30 kDa. }\end{array}$ & any & 34 & 13 & 40 to 80 & 4 to 21 \\
\hline $\begin{array}{l}\text { Protein sequence } \\
\text { coverage } \geq 40 \% \\
\text { and a closest } \\
\text { ortholog } \leq 90 \% \\
\left(\mathrm{NCBI}^{\mathrm{C}} \text { non }\right. \\
\text { redundant protein } \\
\text { sequence database } \\
\left.\text { and ToxoDB }{ }^{d}\right) \text {. }\end{array}$ & $\begin{array}{l}\text { ST-33 kDa, ST-32 kDa, } \\
\text { MT-32 kDa, } \\
\text { MT-30 kDa. }\end{array}$ & $\geq 90$ & 19 & 7 & 41 to 80 & 4 to 13 \\
\hline
\end{tabular}

Table 3: Filtering criteria applied to nanoLC-MS/MS to identify specific immunogenic proteins of $T$. gondii.

These proteins are: SAG-related sequence SRS34A, dense granule protein GRA7, dense granule protein GRA1, dense granule protein DG32, microneme protein MIC5, rhoptry protein ROP5 and Toxofilin.

The Blastp of the 7 proteins with ToxoDB database to check the homology of these proteins against their closest relatives (other Toxoplasma strains and Hammondia, Neospora, and Eimeria) showed a $86 \%$ to $100 \%$ homology with proteins of both VEG and ME49 strains of $T$. gondii and a $58 \%$ to $87 \%$ homology with Hammondia hammondi (Table 4). The blastp against NCBI non-redundant database confirmed the homology with $\mathrm{H}$. hammondi proteins and eliminated any similarity with proteins from human (the host) or from other related species.

\section{Discussion}

In our study, we identified 7 potential immunogenic proteins which seem to be very useful in the serodiagnosis of toxoplasmosis in immunocompetent individuals. For this purpose, we used the combination of $1 \mathrm{D}$ electrophoresis, immunoblot, nanoLC-MS/MS and bioinformatics analysis. This approach is a high throughput immunoproteomics method to identify immunodominant antigens with diagnostic value [6]. In contrast to two-dimensional (2D) electrophoresis known to have a higher resolution power, 1D electrophoresis is more suitable for the separation of membrane proteins that may precipitate under isoelectric focusing conditions in $2 \mathrm{D}$ electrophoresis and of proteins with high $\mathrm{pH}$ and molecular weight [21].

In order to select proteins that present strong similarity with $T$. gondii sequences and in the same time the lowest similarity with any non- $T$. gondii sequences, we used a ToxoDB database search with MASCOT followed by a NCBI non-redundant protein database to deduce sequence homology of these 7 proteins against their closest relatives (Hammondia, Neospora, and Eimeria) and other organisms including humans $[14,22]$.

The 7 proteins were selected according to the following highly selective criteria: (i) specificity of the revealed band $\geq 90 \%$ in 
Citation: Khammari I, Lakhal S, Westermann B, Benkahla A, Bouratbine A, et al. (2015) Characterization of Soluble and Membrane-Bound Proteins of Toxoplasma gondii as Diagnostic Markers of Infection. J Bacteriol Parasitol 6: 239. doi:10.4172/2155-9597.1000239

Page 6 of 10

immunoblot, (ii) proteins sequence coverage $\geq 40 \%$ and closest ortholog $\leq 90 \%$ in MS/MS. These proteins are: SRS34A, GRA7, GRA1, DG32, MIC5, ROP5 and Toxofilin.

\begin{tabular}{|c|c|c|c|c|c|c|c|c|}
\hline Protein name & $\begin{array}{l}\text { Length } \\
\text { (amino } \\
\text { acids) }\end{array}$ & $\begin{array}{l}\text { Bands } \\
\mathrm{kDa}^{\mathrm{a}}\end{array}$ & $\begin{array}{l}\text { Theoretic } \\
\text { al } \\
\text { molecula } \\
\text { r weight } \\
\mathrm{kD}^{\mathrm{a}}\end{array}$ & $\begin{array}{l}\text { Protein accession } \\
\text { numbers }\end{array}$ & $\begin{array}{l}\text { Homology } \\
\text { with ME49 and VEG } \\
\text { strains }\end{array}$ & $\begin{array}{lr}\text { Homology } & \text { with } \\
\text { Eimeria, } & \\
\text { Hammondia } & \text { and } \\
\text { Neospora } & \text { in } \\
\text { ToxoDBb } & \end{array}$ & $\begin{array}{lr}\text { Homology } & \text { with } \\
\text { other } & \text { related } \\
\text { organisms in NCBlc }\end{array}$ & $\begin{array}{l}\text { Percentage } \\
\text { sequence } \\
\text { Coverage (\%) }\end{array}$ \\
\hline $\begin{array}{l}\text { SAG-related } \\
\text { sequence } \\
\text { SRS34A } \\
\text { (SAG2A)/T. } \\
\text { gondii GT1 }\end{array}$ & 186 & $\begin{array}{l}\text { MTd-30 kDa } \\
\text { MT-32 kDa }\end{array}$ & 18.980 & TGGT1_271050 & $\begin{array}{l}\text { 100\% } \\
\text { TGVEG_271050 } \\
99 \% \\
\text { TGME49_271050 }\end{array}$ & $\begin{array}{l}83 \% \\
\text { HHA_271050 } \\
\text { Hammondia } \\
\text { hammondi } \\
\text { (strain_H.H.34) }\end{array}$ & $\begin{array}{l}82 \% \\
\text { XP_008882475.1 } \\
\text { Hammondia } \\
\text { hammondi }\end{array}$ & 43 \\
\hline $\begin{array}{l}\text { dense granule } \\
\text { protein } \\
\text { GRA7/T. } \\
\text { gondii GT1 }\end{array}$ & 236 & $\begin{array}{l}\text { STe-33 kDa } \\
\text { MT-30 kDa } \\
\text { MT-32 kDa }\end{array}$ & 25.857 & TGGT1_203310 & $\begin{array}{l}\text { 99\% } \\
\text { TGME49_203310 } \\
\text { 97\% TGVEG_203310 }\end{array}$ & $\begin{array}{l}60 \% \\
\text { HHA_203310 } \\
\text { Hammondia } \\
\text { hammondi } \\
\text { (strain_H.H.34) }\end{array}$ & $\begin{array}{l}60 \% \\
\text { XP_008884816.1 } \\
\text { Hammondia } \\
\text { hammondi }\end{array}$ & 50 \\
\hline $\begin{array}{l}\text { dense granule } \\
\text { protein } \\
\text { GRA1/T. } \\
\text { gondii GT1 }\end{array}$ & 190 & $\begin{array}{l}\mathrm{ST}-32 \mathrm{kDa} \\
\mathrm{ST}-33 \mathrm{kDa} \\
\mathrm{MT}-30 \mathrm{kDa} \\
\mathrm{MT}-32 \mathrm{kDa}\end{array}$ & 20.149 & TGGT1_270250 & $\begin{array}{l}\text { 99\% TGVEG_270250 } \\
98 \% \\
\text { TGME49_270250 }\end{array}$ & $\begin{array}{l}85 \% \\
\text { HHA_270250 } \\
\text { Hammondia } \\
\text { hammondi } \\
\text { (strain_H.H.34) }\end{array}$ & $\begin{array}{l}84 \% \\
\text { XP_00888240.1 } \\
\text { Hammondia } \\
\text { hammondi }\end{array}$ & 51 \\
\hline $\begin{array}{l}\text { dense granule } \\
\text { protein } \\
\text { DG32/T. gondii } \\
\text { GT1 }\end{array}$ & 219 & MT-30 kDa & 24.154 & TGGT1_297880 & $\begin{array}{l}\text { 99\% TGVEG_297880 } \\
99 \% \\
\text { TGME49_297880 }\end{array}$ & $\begin{array}{l}87 \% \\
\text { HHA_297880 } \\
\text { Hammondia } \\
\text { hammondi } \\
\text { (strain_H.H.34) }\end{array}$ & $\begin{array}{l}87 \% \\
\text { XP_008886071.1 } \\
\text { Hammondia } \\
\text { hammondi }\end{array}$ & 43 \\
\hline $\begin{array}{l}\text { microneme } \\
\text { protein } \\
\text { MIC5/T. gondii } \\
\text { GT1 }\end{array}$ & 181 & $\begin{array}{l}\text { ST-32 kDa } \\
\text { ST-33 kDa } \\
\text { MT-30 kDa }\end{array}$ & 19.930 & TGGT1_277080 & $\begin{array}{l}\text { 99\% } \\
\text { TGME49_277080 } \\
\text { 99\% TGVEG_277080 }\end{array}$ & $\begin{array}{l}87 \% \\
\text { HHA_277080 } \\
\text { Hammondia } \\
\text { hammondi } \\
\text { (strain_H.H.34) }\end{array}$ & $\begin{array}{l}86 \% \\
\text { XP_008888560.1 } \\
\text { Hammondia } \\
\text { hammondi }\end{array}$ & 44 \\
\hline $\begin{array}{l}\text { rhoptry protein } \\
\text { ROP } 5 / T \text {. } \\
\text { gondii GT1 }\end{array}$ & 549 & $\mathrm{ST}-33 \mathrm{kDa}$ & 60.777 & TGGT1_308090 & $\begin{array}{l}\text { 100\% } \\
\text { TGVEG_308090 } \\
97 \% \\
\text { TGME49_308090 }\end{array}$ & $\begin{array}{l}58 \% \\
\text { HHA_308096 } \\
\text { Hammondia } \\
\text { hammondi } \\
\text { (strain_H.H.34) }\end{array}$ & $\begin{array}{l}75 \% \\
\text { AlT72053.1 } \\
\text { Hammondia } \\
\text { hammondi }\end{array}$ & 43 \\
\hline $\begin{array}{l}\text { Toxofilin } \\
\text { gondii GT1 }\end{array}$ & 245 & $\begin{array}{l}\text { ST-33 kDa } \\
\text { MT-30 kDa }\end{array}$ & 27.132 & TGGT1_214080 & $\begin{array}{l}97 \% \\
\text { TGME49_214080 } \\
86 \% \text { TGVEG_214080 }\end{array}$ & $\begin{array}{l}59 \% \\
\text { HHA_214080 } \\
\text { Hammondia } \\
\text { hammondi } \\
\text { (strain_H.H.34 ) }\end{array}$ & $\begin{array}{l}58 \% \\
\text { XP_008885392.1 } \\
\text { Hammondia } \\
\text { hammondi }\end{array}$ & 49 \\
\hline
\end{tabular}

Table 4: List of proteins candidate of $T$. gondii retained after nanoLC-MS/MS analysis for the development of a diagnosis toolkit.

SRS34A: formerly SAG2A, SRS34A is one of the major surface antigens of the tachyzoite form [23-25]. It has a theoretical molecular weight of $18.980 \mathrm{kDa}$ and is composed of 186 amino acids. In our study, this protein was only identified in the membrane fraction of tachyzoites (MT-30 kDa and MT-32 kDa bands). It appears to play a role in host cell invasion, immune modulation, virulence attenuation, and it may also promote the parasite survival in the host cell $[23,24,26,27]$.
SRS34A is known as an immunodominant antigen and as a good marker of infection. Its usefulness in the serodiagnosis of toxoplasmosis was evaluated in many studies [24,28-30]. It was shown to be very sensitive in the detection of $\operatorname{IgG}$. Fong et al. using a recombinant form of SRS34A showed that the protein was recognized by all Toxoplasma positive sera in immunoblot analysis, while in ELISA, the sensitivity varied from $80 \%$ in patients with acute infection to $100 \%$ in patients with chronic infection [31]. In contrast, the 
majority of investigators underlined the usefulness of SRS34A as a diagnostic tool of the acute phase of toxoplasmosis, with a sensitivity ranging from $90 \%$ to $100 \%$ against $67 \%$ to $70 \%$ in the chronic phase $[24,32-36]$.

In our study, SRS34A was identified within the MT-30 kDa band that showed a sensitivity of $76.2 \%$ and a specificity of $99.0 \%$; and in the MT-32 kDa band that showed a sensitivity of $62.7 \%$ and a specificity of $97.9 \%$. Our findings argue for the relevance of SRS34A in the serodiagnosis of toxoplasmosis.

GRA7: is a dense granule protein composed of 236 amino acids. It has a theoretical molecular weight of $25.857 \mathrm{kDa}$. It is expressed by both tachyzoite and bradyzoite stages. It is abundant on the surface and in the cytoplasmic matrix of the host cell, the parasitophore vacuole membrane and within the parasitophore lumen [37-39]. Like all GRA proteins, GRA7 is involved in host cell invasion and associated with the parasite membrane complex, with the tubular elements of the intravacuolar network and with the parasitophorous vacuole membrane through the intravacuolar network during the invasion process [37]. When GRA7 is released from tachyzoites and bradyzoites, it has direct contact with the host immune system, and induces a strong antibody response in both early and late stages of infection $[33,40]$.

GRA7 has been reported as a good marker of infection and showed to be much more sensitive than ROP1, SAG1 and GRA8 that were not included among proteins selected in our study [39]. According to Neudeck et al. GRA7 induces antibodies response earlier than other antigens, such SAG1 and MAG [41].

The overall sensitivity of GRA7 ranged between $81 \%$ and $88 \%$ and its specificity between $98 \%$ and $100 \%[32,33,35,39,41]$. The majority of authors demonstrated the usefulness of GRA7 as a diagnostic marker of the acute phase of toxoplasmosis, with a sensitivity ranging from $94 \%$ to $96 \%$ against $79 \%$ to $89 \%$ in the chronic phase of infection [32,39,42-44]. In contrast, Pietkiewicz et al. showed a sensitivity of $68.9 \%$ in acute infection and $78 \%$ in chronic infection [45]. Altchech et al. underlined the usefulness of GRA7 in the diagnosis of congenital toxoplasmosis [46].

In our study, GRA7 was identified in ST-33 kDa band that showed a sensitivity of $71.6 \%$ and a specificity of $93.0 \%$ and in both MT-30 kDa and MT-32 kDa bands that showed a sensitivity of $76.2 \%$ and $62.7 \%$, respectively; and a specificity of $99.0 \%$ and $97.9 \%$, respectively. These findings argue for the potential of GRA7 as a serodiagnosis marker of toxoplasmosis infection.

GRA1: is expressed and secreted by both the tachyzoite and the bradyzoite stages. It has a theoretical molecular weight of $20.149 \mathrm{kDa}$ and is composed of 190 amino acids. The protein is secreted into the parasitophore vacuole and plays an important role in host cell invasion [47-49]. GRA1 is also associated with strong stimulation of the host immune system $[47,50,51]$. The overall sensitivity of ELISA using the recombinant form of the protein in the detection of anti-Toxoplasma IgG varies from $60 \%$ to $98 \%[33,47,48,52]$. The protein was described as a good marker of the chronic phase of toxoplasmosis. Ferrandiz et al. reported a sensitivity of the protein of $78.2 \%$ in chronic infection against $34 \%$ in acute infection [48]. However, recent serological studies showed that GRA1 can be used to detect specific IgG in sera of both acute and chronic phase of disease with a similar sensitivities $[33,45,51]$. In our study, GRA1 was identified in ST-32 kDa and ST-33 $\mathrm{kDa}$ bands that showed a sensitivity of $93.3 \%$ and $71.3 \%$, respectively, and a specificity of $92.0 \%$ and $93.0 \%$, respectively; and in MT-30 kDa and MT-32 kDa bands that showed a sensitivity of $76.2 \%$ and $62.7 \%$, respectively and a specificity of $99.0 \%$ and $97.9 \%$ respectively. Our findings suggest a potential serodiagnosis role of this protein in the diagnosis of toxoplasmosis.

DG32: is an antigen of the dense granules [53], composed of 219 amino acids. It has a theoretical molecular weight of $24.154 \mathrm{kDa}$. DG32 participate in the maintenance of intracellular parasitism in almost all nucleated host cells [54]. To our knowledge, the immunogenicity of this antigen has been poorly evaluated. However, according to our results, this protein can be considered as a serodiagnosis marker of toxoplasmosis because it was identified in the $30 \mathrm{kDa}$ band that showed a sensitivity of $76.2 \%$ and a nearly absolute specificity of $99.0 \%$.

MIC5: is a small soluble micronemal protein composed of 181 amino acids. It has a theoretical molecular weight of $19.930 \mathrm{kDa}$. Like all micronemes proteins, it contains a transmembrane domain [55]. It appears to be one of the most abundant secretory proteins and was shown to be necessary for the correct trimming of invasion-related proteins on the parasite surface [56]. MIC5 seems to be strongly immunogenic [57]. However, the serodiagnosis value of this protein remains poorly documented.

In our work, MIC5 was identified within the ST-32 kDa and ST-33 $\mathrm{kDa}$ bands that showed a sensitivity of $93.3 \%$ and $71.3 \%$, respectively; and in MT-30 kDa band that showed a sensitivity of $76.2 \%$ and a specificity of $99.0 \%$. These findings suggest a potential role of the MIC5 in the diagnosis of toxoplasmosis.

ROP5: it is a pseudokinase composed of 549 amino acids. It has a theoretical molecular weight of $60.777 \mathrm{kDa}$. ROP5 has been recognized as a key virulence factor of $T$. gondii [58-61].

To date, little is known about the immunogenicity and the mechanisms of immune response induced by ROP5. According to Grybowski et al. ROP5 induces an early IgM response in the acute stage of infection, while the specific IgG response is rather moderate [61].

In our study, ROP5 was only detected in the ST-33 kDa band that showed a sensitivity of $71.6 \%$ and a specificity of $93.0 \%$ suggesting the usefulness of ROP5 as an additional marker of serodiagnosis.

Toxofilin: is a $27.132 \mathrm{kDa}$ monomeric actin-binding protein composed of a 245 amino acids. It is secreted by the rhoptries and is involved in host cell invasion $[62,63]$. Toxofilin is known for its ability to bind to parasite and mammalian actin and for its role in the regulation of actin filament disassembly and turnover [64-66]. The immunogenicity of Toxofilin is still unclear and its relevance as a serodiagnosis tool poorly evaluated. However, our findings indicate that Toxofilin could be a valuable marker of toxoplasmosis. Indeed, the protein was detected in ST- $33 \mathrm{kDa}$ band that showed a sensitivity of $71.6 \%$ and a specificity of $93.0 \%$ and in MT-30 $\mathrm{kDa}$ band that showed a sensitivity of $76.2 \%$ and a specificity of $99.0 \%$.

According to most previous data, it is noted that the specificity of the seven reactive $T$. gondii proteins is mostly $>90 \%$ but their sensitivity is around $70 \%$. This may be due to the fact that the proteins were present in only low concentrations in the antigen extract.

The analysis of our results according to the IgM response showed that the MT-30 kDa band was much more frequently revealed by IgG positive and IgM negative sera as compared to IgG positive and IgM positive sera $\left(\mathrm{p}<10^{-4}\right)$ (unpublished results). Six of the seven selected 
proteins were identified in the MT-30 kDa band. This finding suggest that the reactivity to the six proteins may vary according to IgM response and hence to the stage of infection. The absence of IgM response usually characterizes the chronic phase of infection. However, the differential reactivity of positive sera against the seven proteins needs to be investigated in order to assess the relevance of these proteins in dating toxoplasmosis infection. In this respect, it would be much interesting to test the seven different proteins against antibodies produced over time in an experimental animal model of $T$. gondii infection.

It is worth mentioning that the 7 proteins we described herein and we extracted from the GT1 virulent strain of $T$. gondii showed a $86 \%$ to $100 \%$ homology with both VEG and ME49 strains. These findings argue for the relevance of these proteins in the serodiagnosis of toxoplasmosis infection independently of the strain causing the disease. On the other hand, our bioinformatic approach revealed a $58 \%$ to $87 \%$ homology between $T$. gondii and H. hammondi. Both species are known to have not only morphological but also antigenic similarities and serological cross-reactions between both organisms have been described [67-70]. It is worthy to note that $H$. hammondi has never been shown to infect humans.

In conclusion, according to our findings, the seven proteins we described in the present study appear to be highly valuable markers of acquired toxoplasmosis in immunocompetent individuals. The use of the recombinant form of these proteins may have many advantages with respect to the standardization of serological techniques. Finally, since there may be differences of reactivity of the seven $T$. gondii proteins identified, it should be considered to produce and optimize mixtures of those proteins in order to achieve comprehensive capture of $T$. gondii-specific serum antibodies.

\section{Acknowledgment}

Special thanks to the International Network of Pasteur Institute for giving access to their Higher Performance Computing (HPC) resources to facilitate the process and analysis of our data. This work used the computational and storage services (BIC cluster) provided by the IT department of Pasteur Institute, Paris.

\section{References}

1. Robert-Gangneux F, Dardé ML (2012) Epidemiology of and diagnostic strategies for toxoplasmosis. Clin Microbiol Rev 25: 264-296.

2. Ma GY, Zhang JZ, Yin GR, Zhang JH, Meng XL, et al. (2009) Toxoplasma gondii: proteomic analysis of antigenicity of soluble tachyzoite antigen. Exp Parasitol 122: 41-46.

3. Holec-Gasior L (2013) Toxoplasma gondii recombinant antigens as tools for serodiagnosis of human toxoplasmosis: current status of studies. Clin Vaccine Immunol 20: 1343-1351.

4. Dubey JP (2008) The history of Toxoplasma gondii--the first 100 years. J Eukaryot Microbiol 55: 467-475.

5. Flori P, Chene G, Varlet MN, Sung RT (2009) [Toxoplasma gondii serology in pregnant woman: characteristics and pitfalls]. Ann Biol Clin (Paris) 67: 125-133.

6. Sun XM, Ji YS, Elashram SA, Lu ZM, Liu XY, et al. (2012) Identification of antigenic proteins of Toxoplasma gondii RH strain recognized by human immunoglobulin G using immunoproteomics. J Proteomics 77: 423-432.

7. Montoya JG, Remington JS (2008) Management of Toxoplasma gondii infection during pregnancy. Clin Infect Dis 47: 554-566.
8. Hruzik A, Asif AR, Gross U (2011) Identification of Toxoplasma gondii SUB1 antigen as a marker for acute infection by use of an innovative evaluation method. J Clin Microbiol 49: 2419-2425.

9. Franck J, Garin YJ, Dumon H (2008) LDBio-Toxo II immunoglobulin G Western blot confirmatory test for anti-toxoplasma antibody detection. J Clin Microbiol 46: 2334-2338.

10. Jost C, Touafek F, Fekkar A, Courtin R, Ribeiro M, et al. (2011) Utility of immunoblotting for early diagnosis of toxoplasmosis seroconversion in pregnant women. Clin Vaccine Immunol 18: 1908-1912.

11. Unno A, Suzuki K, Xuan X, Nishikawa Y, Kitoh K, et al. (2008) Dissemination of extracellular and intracellular Toxoplasma gondii tachyzoites in the blood flow. Parasitol Int 57: 515-518.

12. Kositanont U, Saetun P, Krittanai C, Doungchawee G, Tribuddharat C, et al. (2007) Application of immunoproteomics to leptospirosis: towards clinical diagnostics and vaccine discovery. Proteomics Clin Appl 1: 400-409.

13. Weiss LM, Fiser A, Angeletti RH, Kim K (2009) Toxoplasma gondii proteomics. Expert Rev Proteomics 6: 303-313.

14. Yeng C, Osman E, Mohamed Z, Noordin R (2010) Detection of immunogenic parasite and host-specific proteins in the sera of active and chronic individuals infected with Toxoplasma gondii. Electrophoresis 31: 3843-3849.

15. Montgomery CA Jr (1987) Control of animal pain and distress in cancer and toxicologic research. J Am Vet Med Assoc 191: 1277-1281.

16. Robinson SA, Smith JE, Millner PA (2004) Toxoplasma gondii major surface antigen (SAG1): in vitro analysis of host cell binding. Parasitology 128: 391-396.

17. Laemmli UK (1970) Cleavage of structural proteins during the assembly of the head of bacteriophage T4. Nature 227: 680-685.

18. Carapito C, Burel A, Guterl P, Walter A, Varrier F, et al. (2014) MSDA, a proteomics software suite for in-depth Mass Spectrometry Data Analysis using grid computing. Proteomics 14: 1014-1019.

19. Elias JE, Gygi SP (2007) Target-decoy search strategy for increased confidence in large-scale protein identifications by mass spectrometry. Nat Methods 4: 207-214.

20. Altschul SF, Madden TL, Schäffer AA, Zhang J, Zhang Z, et al. (1997) Gapped BLAST and PSI-BLAST: a new generation of protein database search programs. Nucleic Acids Res 25: 3389-3402.

21. Fang Y, Robinson DP, Foster LJ (2010) Quantitative analysis of proteome coverage and recovery rates for upstream fractionation methods in proteomics. J Proteome Res 9: 1902-1912.

22. Xia D, Sanderson SJ, Jones AR, Prieto JH, Yates JR, et al. (2008) The proteome of Toxoplasma gondii: integration with the genome provides novel insights into gene expression and annotation. Genome Biol 9: R116.

23. Parmley SF, Sgarlato GD, Mark J, Prince JB, Remington JS (1992) Expression, characterization, and serologic reactivity of recombinant surface antigen P22 of Toxoplasma gondii. J Clin Microbiol 30: 1127-1133.

24. Béla SR, Oliveira Silva DA, Cunha-Júnior JP, Pirovani CP, Chaves-Borges FA, et al. (2008) Use of SAG2A recombinant Toxoplasma gondii surface antigen as a diagnostic marker for human acute toxoplasmosis: analysis of titers and avidity of IgG and IgG1 antibodies. Diagn Microbiol Infect Dis 62: 245-254.

25. Wasmuth JD, Pszenny V, Haile S, Jansen EM, Gast AT, et al. (2012) Integrated bioinformatic and targeted deletion analyses of the SRS gene superfamily identify SRS29C as a negative regulator of Toxoplasma virulence. MBio 3.

26. Harning D, Spenter J, Metsis A, Vuust J, Petersen E (1996) Recombinant Toxoplasma gondii surface antigen 1 (P30) expressed in Escherichia coli is recognized by human Toxoplasma-specific immunoglobulin M (IgM) and IgG antibodies. Clin Diagn Lab Immunol 3: 355-357.

27. Manger ID, Hehl AB, Boothroyd JC (1998) The surface of Toxoplasma tachyzoites is dominated by a family of glycosylphosphatidylinositolanchored antigens related to SAG1. Infect Immun 66: 2237-2244. 
28. Carvalho FR, Silva DA, Cunha-Júnior JP, Souza MA, Oliveira TC, et al. (2008) Reverse enzyme-linked immunosorbent assay using monoclonal antibodies against SAG1-related sequence, SAG2A, and p97 antigens from Toxoplasma gondii to detect specific immunoglobulin G (IgG), IgM, and IgA antibodies in human sera. Clin Vaccine Immunol 15: 1265-1271.

29. Santana SS, Silva DA, Vaz LD, Pirovani CP, Barros GB, et al. (2012) Analysis of IgG subclasses (IgG1 and IgG3) to recombinant SAG2A protein from Toxoplasma gondii in sequential serum samples from patients with toxoplasmosis. Immunol Lett 143: 193-201.

30. Macêdo AG Jr, Cunha JP Jr, Cardoso TH, Silva MV, Santiago FM, et al. (2013) SAG2A protein from Toxoplasma gondii interacts with both innate and adaptive immune compartments of infected hosts. Parasit Vectors 6: 163.

31. Fong MY, Lau YL, Zulqarnain M (2008) Characterization of secreted recombinant Toxoplasma gondii surface antigen 2 (SAG2) heterologously expressed by the yeast Pichia pastoris. Biotechnol Lett 30: 611-618.

32. Jacobs D, Vercammen M, Saman E (1999) Evaluation of recombinant dense granule antigen 7 (GRA7) of Toxoplasma gondii for detection of immunoglobulin $\mathrm{G}$ antibodies and analysis of a major antigenic domain. Clin Diagn Lab Immunol 6: 24-29.

33. Lecordier L, Fourmaux MP, Mercier C, Dehecq E, Masy E, et al. (2000) Enzyme-linked immunosorbent assays using the recombinant dense granule antigens GRA6 and GRA1 of Toxoplasma gondii for detection of immunoglobulin G antibodies. Clin Diagn Lab Immunol 7: 607-611.

34. Lekutis C, Ferguson DJ, Boothroyd JC (2000) Toxoplasma gondii: identification of a developmentally regulated family of genes related to SAG2. Exp Parasitol 96: 89-96.

35. Golkar M, Rafati S, Abdel-Latif MS, Brenier-Pinchart MP, FrickerHidalgo H, et al. (2007) The dense granule protein GRA2, a new marker for the serodiagnosis of acute Toxoplasma infection: comparison of sera collected in both France and Iran from pregnant women. Diagn Microbiol Infect Dis 58: 419-426.

36. Holec L, Hiszczynska-Sawicka E, Gasior A, Brillowska-Dabrowska A, Kur J (2007) Use of MAG1 recombinant antigen for diagnosis of Toxoplasma gondii infection in humans. Clin Vaccine Immunol 14: 220-225.

37. Bonhomme A, Maine GT, Beorchia A, Burlet H, Aubert D, et al. (1998) Quantitative immunolocalization of a P29 protein (GRA7), a new antigen of toxoplasma gondii. J Histochem Cytochem 46: 1411-1422.

38. Fischer HG, Stachelhaus S, Sahm M, Meyer HE, Reichmann G (1998) GRA7, an excretory $29 \mathrm{kDa}$ Toxoplasma gondii dense granule antigen released by infected host cells. Mol Biochem Parasitol 91: 251-262.

39. Pfrepper KI, Enders G, Gohl M, Krczal D, Hlobil H, et al. (2005) Seroreactivity to and avidity for recombinant antigens in toxoplasmosis. Clin Diagn Lab Immunol 12: 977-982.

40. Jacobs D, Dubremetz JF, Loyens A, Bosman F, Saman E (1998) Identification and heterologous expression of a new dense granule protein (GRA7) from Toxoplasma gondii. Mol Biochem Parasitol 91: 237-249.

41. Neudeck A, Stachelhaus S, Nischik N, Striepen B, Reichmann G, et al. (2002) Expression variance, biochemical and immunological properties of Toxoplasma gondii dense granule protein GRA7. Microbes Infect 4: 581-590.

42. Kotresha D, Poonam D, Muhammad Hafiznur Y, Saadatnia G Nurulhasanah O, et al. (2012) Recombinant proteins from new constructs of SAG1 and GRA7 sequences and their usefulness to detect acute toxoplasmosis. Trop Biomed 29: 129-137.

43. Sadeghiani G, Zare M, Babaie J, Shokrgozar MA, Azadmanesh K, et al. (2009) Heterologous production of dense granule GRA7 antigen of Toxoplasma gondii in Escherichia coli. Southeast Asian J Trop Med Public Health 40: 692-700.

44. Selseleh M, Keshavarz H, Mohebali M, Shojaee S, Selseleh M, et al. (2012) Production and evaluation of Toxoplasma gondii recombinant GRA7 for serodiagnosis of human infections. Korean J Parasitol 50: 233-238.
45. Pietkiewicz H, Hiszczynska-Sawicka E, Kur J, Petersen E, Nielsen HV, et al. (2007) Usefulness of Toxoplasma gondii recombinant antigens (GRA1, GRA7 and SAG1) in an immunoglobulin G avidity test for the serodiagnosis of toxoplasmosis. Parasitol Res 100: 333-337.

46. Altcheh J, Diaz NS, Pepe CM, Martin V, Nigro M, et al. (2006) Kinetic analysis of the humoral immune response against 3 Toxoplasma gondiirecombinant proteins in infants with suspected congenital toxoplasmosis. Diagn Microbiol Infect Dis 56: 161-165.

47. Cesbron-Delauw MF, Guy B, Torpier G, Pierce RJ, Lenzen G, et al. (1989) Molecular characterization of a 23-kilodalton major antigen secreted by Toxoplasma gondii. Proc Natl Acad Sci U S A 86: 7537-7541.

48. Ferrandiz J, Mercier C, Wallon M, Picot S, Cesbron-Delauw MF, et al. (2004) Limited value of assays using detection of immunoglobulin $G$ antibodies to the two recombinant dense granule antigens, GRAl and GRA6 Nt of Toxoplasma gondii, for distinguishing between acute and chronic infections in pregnant women. Clin Diagn Lab Immunol 11: 1016-1021.

49. Wang Z, Ge W, Huang SY, Li J, Zhu XQ, et al. (2014) Evaluation of recombinant granule antigens GRA1 and GRA7 for serodiagnosis of Toxoplasma gondii infection in dogs. BMC Vet Res 10: 158

50. Coppens I, Andries M, Liu JL, Cesbron-Delauw MF (1999) Intracellular trafficking of dense granule proteins in Toxoplasma gondii and experimental evidences for a regulated exocytosis. Eur J Cell Biol 78: 463-472.

51. Ferra B, Holec-Gasior L, Kur J (2015) A new Toxoplasma gondii chimeric antigen containing fragments of SAG2, GRA1, and ROP1 proteins-impact of immunodominant sequences size on its diagnostic usefulness. Parasitol Res 114: 3291-3299.

52. Behnke MS, Zhang TP, Dubey JP, Sibley LD (2014) Toxoplasma gondii merozoite gene expression analysis with comparison to the life cycle discloses a unique expression state during enteric development. BMC Genomics 15: 350.

53. Beghetto E, Pucci A, Minenkova O, Spadoni A, Bruno L, et al. (2001) Identification of a human immunodominant B-cell epitope within the GRA1 antigen of Toxoplasma gondii by phage display of cDNA libraries. Int J Parasitol 31: 1659-1668.

54. Nam HW (2009) GRA proteins of Toxoplasma gondii: maintenance of host-parasite interactions across the parasitophorous vacuolar membrane. Korean J Parasitol 47 Suppl: S29-37.

55. Gaji RY, Flammer HP, Carruthers VB (2011) Forward targeting of Toxoplasma gondii proproteins to the micronemes involves conserved aliphatic amino acids. Traffic 12: 840-853.

56. Brydges SD, Harper JM, Parussini F, Coppens I, Carruthers VB (2008) A transient forward-targeting element for microneme-regulated secretion in Toxoplasma gondii. Biol Cell 100: 253-264.

57. Beghetto E, Spadoni A, Buffolano W, Del Pezzo M, Minenkova O, et al. (2003) Molecular dissection of the human B-cell response against Toxoplasma gondii infection by lambda display of cDNA libraries. Int J Parasitol 33: 163-173.

58. El Hajj H, Demey E, Poncet J, Lebrun M, Wu B, et al. (2006) The ROP2 family of Toxoplasma gondii rhoptry proteins: proteomic and genomic characterization and molecular modeling. Proteomics 6: 5773-5784.

59. Behnke MS, Fentress SJ, Mashayekhi M, Li LX, Taylor GA, et al. (2012) The polymorphic pseudokinase ROP5 controls virulence in Toxoplasma gondii by regulating the active kinase ROP18. PLoS Pathog 8: e1002992.

60. Etheridge RD, Alaganan A, Tang K, Lou HJ, Turk BE, et al. (2014) The Toxoplasma pseudokinase ROP5 forms complexes with ROP18 and ROP17 kinases that synergize to control acute virulence in mice. Cell Host Microbe 15: 537-550.

61. Grzybowski MM, Dziadek B, Dziadek J, Gatkowska J, Dzitko K, et al. (2015) Toxoplasma gondii: cloning, expression and immunoreactivity of recombinant ROP5 and ROP18 antigens. Exp Parasitol 150: 1-6.

62. Lee SH, Hayes DB, Rebowski G, Tardieux I, Dominguez R (2007) Toxofilin from Toxoplasma gondii forms a ternary complex with an antiparallel actin dimer. Proc Natl Acad Sci USA 104: 16122-16127. 
Citation: Khammari I, Lakhal S, Westermann B, Benkahla A, Bouratbine A, et al. (2015) Characterization of Soluble and Membrane-Bound Proteins of Toxoplasma gondii as Diagnostic Markers of Infection. J Bacteriol Parasitol 6: 239. doi:10.4172/2155-9597.1000239

Page 10 of 10

63. Delorme-Walker V, Abrivard M, Lagal V, Anderson K, Perazzi A, et al (2012) Toxofilin upregulates the host cortical actin cytoskeleton dynamics, facilitating Toxoplasma invasion. J Cell Sci 125: 4333-4342.

64. Poupel O, Boleti H, Axisa S, Couture-Tosi E, Tardieux I (2000) Toxofilin, a novel actin-binding protein from Toxoplasma gondii, sequesters actin monomers and caps actin filaments. Mol Biol Cell 11: 355-368.

65. Delorme V, Cayla X, Faure G, Garcia A, Tardieux I (2003) Actin dynamics is controlled by a casein kinase II and phosphatase 2C interplay on Toxoplasma gondii Toxofilin. Mol Biol Cell 14: 1900-1912.

66. Lodoen MB, Gerke C, Boothroyd JC (2010) A highly sensitive FRETbased approach reveals secretion of the actin-binding protein toxofilin during Toxoplasma gondii infection. Cell Microbiol 12: 55-66.

67. Weiland G, Rommel M, von Seyerl F (1979) Serological cross-reactions between toxoplasma and hammondia. Zentralbl Bakteriol Orig A 244: 391-393.
68. Riahi H, Bouteille B, Darde ML (1998) Antigenic similarity between Hammondia hammondi and Toxoplasma gondii tachyzoites. J Parasitol 84: 651-653.

69. Dubey JP, Sreekumar C (2003) Redescription of Hammondia hammondi and its differentiation from Toxoplasma gondii. Int J Parasitol 33: 1437-1453.

70. Walzer KA, Adomako-Ankomah Y, Dam RA, Herrmann DC, Schares G, et al. (2013) Hammondia hammondi, an avirulent relative of Toxoplasma gondii, has functional orthologs of known T. gondii virulence genes. Proc Natl Acad Sci U S A 110: 7446-7451. 